\title{
PREPAREDNESS RADIOLOGICAL SERVICES FOR THE COVID-19 EMERGENCY HOSPITAL IN WISMA ATLET KEMAYORAN
}

\author{
Muhammad Irsal ${ }^{1)}$ \\ ${ }^{1}$ Jurusan Teknik Radiodiagnostik dan Radioterapi, Politeknik Kesehatan Kementerian \\ Kesehatan Jakarta II, Kebayoran Baru, Jakarta Selatan, 12120 \\ E-mail: muhammad.irsal@poltekkesjkt2.ac.id \\ Submitted: $17^{\text {th }}$ July 2021; Accepted: $21^{\text {th }}$ July 2021 \\ https://doi.org/10.36525/sanitas.2021.3
}

\begin{abstract}
Effort reducing the severity of COVID-19, a flattening of the curve is needed which aims to prepare the treatment system so that the capacity of the hospital can treat patients and provide health care workers, to meet the minimum standard of radiological services during the pandemic, therefore necessary planning and control of radiology services to patients. This research is quantitative descriptive by analyzing the data and discussing the literature, the research was conducted in March-June 2020 in the department radiology of the COVID-19 Emergency Hospital in Wisma Atlet Kemayoran. Subjects of the study were department radiology readiness: facilities radiology, equipment, and conditions of workers, analysis of radiological services, as well as radiation protection and safety for workers and patients. Results for radiology facilities and equipment are very adequate in carrying out radiographic examinations, workers equipped with PPE according to standard operating procedures for handling COVID-19, Radiology services based on workload indicator staff need (WISN) analysis required 16 radiographers with an estimated number of chest radiograph examinations of 4000 patients, and 1 medical physicist. In applying for radiation protection, we must pay attention to the principles of distance, time, and shielding
\end{abstract}

Keywords: COVID-19 Pandemic, Preparedness Radiological, Radiation protection

This is an open access journal, and articles are distributed under the terms of the Creative Commons Attribution-Non Commercial-Share Alike 4.0 License, which allows others to remix, tweak, and build upon the work non-commercially, as long as appropriate credit is given and the new creations are licensed under the identical terms. C)2021 Sanitas 


\title{
KESIAPAN PELAYANAN RADIOLOGI RUMAH SAKIT DARURAT PENANGANAN COVID-19 WISMA ATLET KEMAYORAN JAKARTA
}

\begin{abstract}
ABSTRAK
Upaya mengurangi tingkat keparahan akibat COVID-19, diperlukan 'flattening of the curve" yang bertujuan untuk mempersiapkan sistem perawatan agar kapasitas rumah sakit mampu mengobati pasien dan menyediakan petugas pelayanan kesehatan, sehingga untuk mencukupi standar minimal pelayanan radiologi selama masa pandemik, oleh karena itu diperlukan perencanaan dan pengendalian terhadap pelayanan radiologi kepada pasien. Penelitian ini bersifat deskriptif kuantitatf dengan melakukan analisa data dan pembahasan literatur, penelitian dilakukan pada bulan Maret-Juni 2020 di Instalasi Radiologi RSD Penanganan COVID-19 Wisma Atlet Kemayoran. Subjek penelitian yaitu kesiapan instalasi radiologi: kondisi ruangan dan peralatan, kondisi pekerja, analisa pelayanan radiologi, serta proteksi dan keselamatan radiasi. Kesimpulan untuk kondisi ruangan dan peralatan sangat memadai dalam melaksanakan pemeriksaan radiografi,kemudian untuk kondisi pekerja dilengkapi dengan APD sesuai SOP penangana COVID-19, pelayanan radiologi berdasarkan analisa work load indicator staff need (WISN) dibutuhkan 16 radiografer dengan estimasi jumlah pemeriksaan radiografi dada 4000 pasien, dan 1 fisikawan medik. Dalam penerapan proteksi radiasi agar memperhatikan prinsip jarak, waktu dan shielding.
\end{abstract}

Kata kunci: Pandemik COVID-19, Kesiapan radiologi, Proteksi dan keselamatan radiasi

\section{PENDAHULUAN}

World Health Organization (WHO) pada awalnya menyebut penyakit ini sebagai ' Novel Coronavirus-Infected Pneumonia (NCIP)" dengan virus bernama 2019 Novel Coronavirus (2019-nCoV). pada tanggal 11 Februari 2020 secara resmi WHO mengganti menjadi Coronavirus Disease-19 (COVID-19). Pada 24 maret 2020, lebih dari 417.000 kasus COVID19 telah terkonfirmasi diseluruh dunia menurut pelacakan secara online oleh medical journal, the lancet and hosted by john hopskins university (1).

Pandemik COVID-19 berkembang secara cepat diseluruh dunia, di Indonesia kasus pertama secara resmi diumumkan pada tanggal 2 maret 2020. Untuk mengurangi tingkat keparahan akibat terinfeksi oleh COVID-19, diperlukan "flattening of the curve" yang bertujuan untuk mempersiapkan sistem kesehatan agar kapasitas rumah sakit mampu mengobati pasien dan menyediakan petugas pelayanan kesehatan (2). Selama terjadi pandemik COVID-19 sistem kesehatan di rumah sakit mempunyai kebijakan dalam penanganan dengan mengurangi morbiditas dan mortalitas pasien yang terinfeksi COVID-19 melalui diagnosa dini dan melakukan perawatan. Pencegah penyebaran penyakit berfokus pada tenaga kesehatan dan penyedian alat pelindung diri (APD), selain itu penggunaan ventilator untuk mencegah kemungkinan terjadi peningkatan pasien (3).

Berdasarkan penelitian oleh Feng Pan 2020, menjelaskan bahwa gejala awal pasien COVID-19 seperti demam, sesak napas dalam kurung waktu 14 hari (4). Tahap awal (0-4 hari setelah timbul gejala awal) : pada tahap ini Glasess ground opacity dengan distribusi secara 
sub pleural di lobus bagian bawah secara unilateral atau bilateral ini merupakan pola citra yang sangat identik untuk mengenali pasien yang terinfeksi COVID-19. Proses perkembangan (5-8 hari setelah timbul gejala awal) pada tahap ini infeksi sangat cepat dan distribusi ke multi-lobus bilateral dengan pola citra GGO, crazy-paving dan konsolidasi. Tahap puncak (9-13 hari setelah timbul gejala awal) pada tahap ini daerah paru-paru perlahan mengalami peningkatan pola citra konsolidasi. Tahap penyerapan ( $>14$ hari setelah timbul gejala awal) pada tahap ini tidak pola citra GGO karena mengalami penyerapan, sehingga membentuk konsolidas dengan proses citra crazy-paving tidak terjadi. Proses ini dapat terjadi dalam kurung waktu yang panjang sekitar 26 hari.

Pencitraan dada dengan menggunakan CT scan merupakan diagnosa utama untuk mengidentifikasi pasien dengan klinis penyakit pernapasan, akan tetapi dalam kasus pasien COVID-19 belum menjadi pilihan utama untuk diagnosa, hal ini dipengaruhi oleh kesiapan peralatan dan SDM yang tersedia (5). Akan tetapi pecintraan dada dengan CXR dianggap sangat penting untuk penanganan diagnosa COVID-19 apabila perlatan reverse transcriptasepolymerase chain reaction (RT-PCR) tidak tersedia, sehingga dalam kondisi darurat pandemik persiapan peralatan seperti pembangunan laboratorium dan penyediaan peralatan merupakan salah satu hal yang menjadi kendala, akibatnya banyak pasien tidak dapat diidentifikasi dan mungkin tidak dapat menerima perawatan secara tepat (6). Oleh karena itu, dibutuhkan kesiapan instalasi radiologi terkait prosedur pelayanan radiologi selama masa pandemi COVID-19 : menyediakan peralatan dan SDM selama pandemik, membantu dalam penegakan diagnosa, serta perawatan pasien, melakukan pengendalian infeksius di instalasi radiologi (7). Penelitian ini akan menjelaskan tentang kesiapan pelayanan radiologi di Rumah Sakit Darurat Penanganan COVID-19 Wisma Atlet Kemayoran dalam menghadapi masa pandemik COVID-19.

\section{METODE}

Penelitian ini bersifat deskriptif kuantitatf dengan pembahasan literatur, penelitian dilakukan pada bulan Mareti-Juni 2020 di Instalasi Radiologi RSD Penanganan COVID-19 Wisma Atlet Kemayoran Jakarta. Subjek penelitian yaitu kesiapan instalasi radiologi yang terdiri dari : kondisi ruangan, peralatan dan kondisi pekerja, analisa pelayanan radiologi, serta upaya proteksi dan keselamatan radiasi bagi pekerja dan pasien.

Perihitungan beban kerja menggunakan metode work load indicator staff need (WISN), dengan melakukan analisa beban pekerjaan nyata yang dilaksanakan oleh tiap kategori SDM kesehatan pada tiap unit kerja di fasilitas pelayanan kesehatan. Kelebihan metode ini mudah dioperasikan, mudah digunakan, secara teknis mudah diterapkan, komprehensif dan realistis. 
Estimasi hari kerja selama setahun 30 hari/ bulan dengan libur 4 hari/ bulan, waktu kerja efektif dalam satu hari 20 jam untuk radiografer dan 5 jam untuk fisikawan medik. Waktu kerja tersedia $260 \mathrm{jam} / \mathrm{bulan}$ dengan waktu kegiatan pokok 0,5 jam/pasien untuk radiografer dan untuk fisikawan medik waktu kerja tersedia $650 \mathrm{jam} / \mathrm{bulan}$ dengan waktu kegiatan pokok 5 jam/hari. Makan analisa kebutuhan SDM untuk bulan berikutnya dapat dihitung dengan menggunakan persamaan berikut :

Kebutuhan SDM $=\frac{\text { jumlah pelayanan per bulan }}{\text { standar beban kerja }}$

\section{HASIL DAN PEMBAHASAN}

Pencitraan memiliki peran penting dalam diagnosa COVID-19, modiltas CXR dan CT scan menjadi firstline bagi pasien ODP, PDP dan sangat membantu pada tahap pengobatan bagi pasien COVID-19, untuk memantau perubahan selama masa pengobatan (8). Perkembangan diagnosa COVID-19 dari beberapa pertimbangan riwayat klinis, sehingga dibutuhkan tes serologi untuk mendeteksi antigen virus dalam saluran pernapasan atau mendeteksi antibody dengan polymerase chain reaction (PCR). PCR mampu mengidentifikasi virus dengan sangat detil,akan tetapi memiliki kelemahan terlalu sensitif oleh karena dapat mendeteksi sejumlah residu asam nukleat virus. Modifikasi dari PCR menggunakan RNA yang disebut RT-PCR dengan salinan DNA yang sangat banyak sehingga dapat memberikan hasil yang keliru. Selian itu keterbatasan penggunaan RT-PCR salah satunya yaitu hasil uji dapat negatif karena kesalahan zat didalam spesimen sehingga menghambat asam nukleat, selain itu prosedur yang cukup rumit dan peralatan mahal (9).

Dalam masa pandemik prosedur pemeriksaan radiografi dada memiliki peningkatan resiko infeksi COVID-19 akibat peningkatan pasien. Sehingga dibutuhkan pedoman pelayanan radiologi, rumah sakit telah secara independen menentukan bagaimana memodifikasi proses screening selama pandemik COVID-19 (10). Untuk mencukupi standar minimal pelayanan radiologi selama masa pandemik COVID-19 Instalasi radiologi melakukan perencanaan dan pengendalian terhadap pelayanan minimal RS, salah satu bentuk pelayanan minimal radiologi yaitu melakukan pemeriksaan radiografi dada (11). Instalasi radiologi RS Darurat Penanganan COVID-19 memiliki SDM yang terdiri radiografer, fisikawan medik dan dokter spesialis radiologi. Dengan jumlah 11 orang radiografer, 1 fisikawan medik, 3 dokter spesialis radiologi. Kegiatan pelayanan radiologi disesuaikan dengan kondisi dilapangan, SDM dan peralatan. Dengan tugas radiografer dan fisikawan medik di tunjukan pada Tabel 1. 
Instalasi radiologi diseluruh dunia mempunyai masalah yang sama tentang bagaimana pencitraan radiologi membantu dalam mendiagnosa COVID-19 dan mampu mencegah infeksi yang dapat terjadi pada perlatan yang digunakan. CT scan menjadi diagnosa utama untuk mendeteksi COVID-19, tetapi kendala yang terjadi dilapangan yaitu cara melakukan disinfeksi setelah pemeriksaan dilakukan. sehingga pemeriksaan radiografi dada menjadi pilihan kedua setalah pemeriksaan CT scan, karena selain mudah digunakan, juga mudah dalam melakukan disinfeksi (12). Pada pasien dengan penyakit infeksi pernapasan pemeriksaan radiografi dada menjadi prosedur yang paling diandalkan dalam melakukan diagnosa maupun evaluasi. Radiografi dada sangat cepat dan mudah didapatkan, selain itu citra radiografi dada dapat diinterpretasi oleh dokter dan perawat (13). Dalam masa pandemik prosedur pemeriksaan

Tabel 1. Tugas Radiografer dan Fisikawan medik

\begin{tabular}{ll}
\hline Kategori SDM & Kegiatan pokok \\
\hline Radiografer & Penggunaan APD \\
& Disinfektan peralatan radiologi \\
& Disinfektan peralatan radiologi sekali pemeriksaan \\
& Warm up computer radiography \\
& Warm up pesawat sinar-X \\
& Input log book pemeriksaan \\
& Memanggil pasien dan menjelasakan pemeriksaan \\
& Mengatur posisi pasien dan faktor eksposi pesawat untuk pemeriksaan \\
& thorax \\
& Input data pasien kedalam computer radiography (CR) \\
& Melakukan pembacaan pada CR reader \\
& Cetak hasil citra dan kirim ke PACS \\
& Menyerahkan foto ke perawat/ dokter pengirim \\
& Dekontaminasi APD \\
& Evaluasi tata letak ruangan instalasi radiologi \\
& QC Pesawat sinar-X \\
& QC Computer radiography \\
& Analisa data log book pemeriksaan radiografi \\
& Melakukan repeat analysis \\
Evaluasi program proteksi dan keselamatan radiasi & Evaluasi estimasi dosis radiasi pasien \\
Evisikawan mediki program dekontaminasi instalasi radiologi \\
Pembuatan laporan bulanan \\
Administrasi Instalasi Radiologi
\end{tabular}




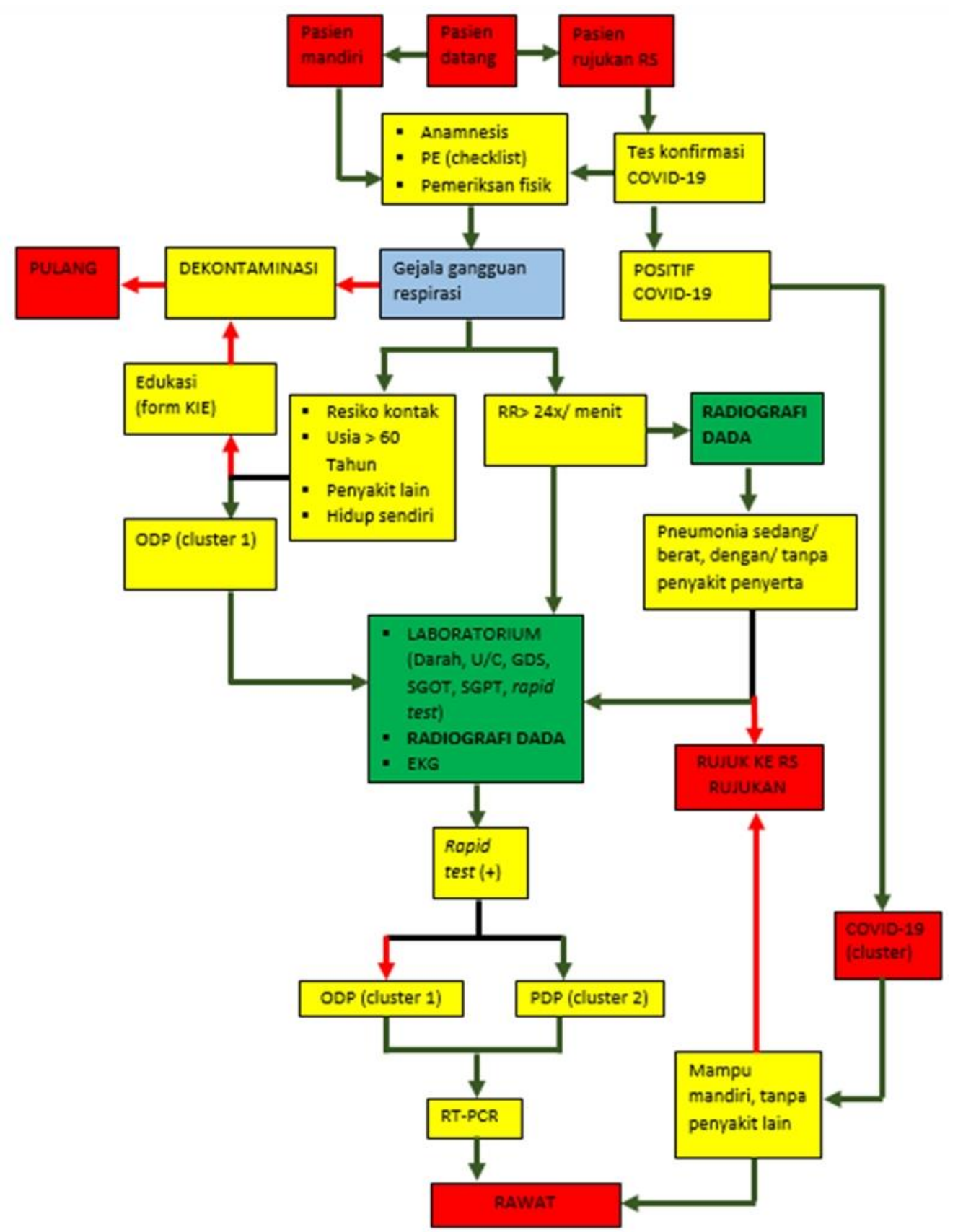

Gambar 1. Skenario Penanganan pasien COVID-19

radiografi dada memiliki peningkatan resiko terjadinya infeksi COVID-19 akibat peningkatan pasien dan pelayanan kesehatan yang mungkin mengalami paparan pada saat pengobatan. Sehingga dibutuhkan kebijakan prosedur penanganan pasien dan proses alur screening COVID-19 (10)

Di Indonesia pengobatan untuk pasien COVID-19 dengan mendirikan Rumah Sakit Darurat Penanganan COVID-19 Wisma Atlet Kemayoran (RSD COVID-19) oleh Gugus Tugas Percepatan Penanganan COVID-19 dibawah Badan Penanggulangan Bencana Nasional (BNPB) dengan berkoordinasi bersama dengan beberapa kementerian dan Puskes TNI. Secara 
umum ada beberapa skenario dalam penanganan pasien suspected COVID-19 di RSD COVID19 yang dibagi menjadi : a) Cluster Orang Dalam Pengawasan (ODP), b) Cluster Pasien Dalam Pengawasan (PDP) c) Cluster Pasien COVID-19, yang di tunjukan pada Gambar 1. Skenario ini akan mengalami perubahan mengikuti perkembangan kondisi rumah sakit dari kesediaan peralatan, ketersedian tenaga kesehatan dan perkembangan literatur tentang prosedur dalam penentuan diagnosa COVID-19.

Apabila hasil positif maka pasien masuk cluster pasien COVID-19 dengan keterangan pasien mampu mandiri, tanpa penyakit lain maka akan langsung dirawat dan apabia pasien tidak mampu mandiri dan kondisi dengan penyakit penyerta yang berat maka akan langsung dilakukan rujukan. Pasien setelah melakukan screening kemudian akan diarahkan ke radiologi untuk melakukan pemeriksaan radiografi dilakukan diinstalasi radiologi. Data penelitian terbaru tentang diagnosa COVID-19 pada pasien tanpa gejala dapat dilakukan menggunakan pemeriksaan radiografi dada setelah 14 hari karantina dengan sensitivitas diagnosa 59\%. Pemeriksaan radiografi dada merupakan diagnosa umum untuk mendeteksi pneumonia akibat COVID-19 (14).

RS Darurat Penanganan COVID-19 mempunyai triase yang disesuaikan dengan kondisi pasien. Pasien yang datang secara mandiri dilakukan screening dengan anamnesis, PE (checklist) dan pemeriksaan fisik. Setelah screening apabila tidak mengalami gejala gangguan resprasi maka pasien akan langsung di dekontaminasi dan bisa kembali ke rumah untuk perawatan mandiri. Tetapi untuk pasien dengan gejala gangguan respirasi maka dilakukan diagnosa lanjutan dengan melakukan tracer riwayat kontak, memiliki penyakit lain, dapat hidup sendirian maka akan dimasukan ke dalam kriteria cluster ODP dan langsung dirawat. Adapun pasien dengan kondisi respirasi rate yang lebih $>24 \mathrm{x} /$ menit maka langsung dilakukan pemeriksaan radiografi dada, apabila kondisi respirasi rate lebih $<24 \mathrm{x} /$ menit makan dilakukan tes laboratorium (darah, U/C, GDS, SGOT, SGPT rapid test), radiografi dada, EKG. Dari hasil tersebut pasien didapatkan hasil rapid test positif maka pasien kriteria cluster PDP dan apabila hasil tes negatif pasien masuk kriteria cluster ODP, tetapi apabila hasil pemeriksaan radiografi dada. Apabila pasien terdapat potensi penyakit bawaan berat seperti (pneumonia dan penyakit penyerta) maka akan di rujuk ke RS perawat khusus. Selanjutnya pasien dilakukan tes untuk memastikan COVID-19 dengan menggunakan RT-PCR. Pasien dengan rujukan dari RS Pemerintah/ swasta dilakukan tes konfirmasi COVID-19, tetapi pada umumnya pasien yang dirujukan merupakan pasien dengan diagnosa telah positif. 


\section{a. Kesiapan ruangan dan peralatan}

Instalasi Radiologi RSD Penanganan COVID-19 memiliki satu ruangan pemeriksaan radiografi berukuran 4,8 m x 4,2 $\mathrm{m}$ x $3 \mathrm{~m}$, dengan didukung mobile shielding yang berjumlah 6 buah, dan tembok dengan ketebalan $11 \mathrm{~cm}$ (Gambar 2). Sedangkan untuk peralatan radiologi yang digunakan yaitu pesawat sinar-X mobile, computer radiography $(\mathrm{CR})$, printer film radiografi, Picture Archieving Communication sysytem (PACS). Selain itu juga beberapa peralatan pendukung untuk monitoring radiasi ; TLD, pendose dan Suvey meter. Karena RSD dibangun untuk penangan COVID-19 sehingga pemeriksaan yang sering dilakukan yaitu pemeriksaan radiografi dada Desain ruangan/ tata letak ruangan pemeriksaan radiografi disesuaikan dengan kondisi dilapangan, beban kerja dan evaluasi pengukuran paparan radiasi per minggu, selain itu peninjauhan kondisi ruangan akan dilakukan secara berkelanjutan sebagai upaya proteksi dan keselamatan kepada pekerja, pasien dan masyarakat.

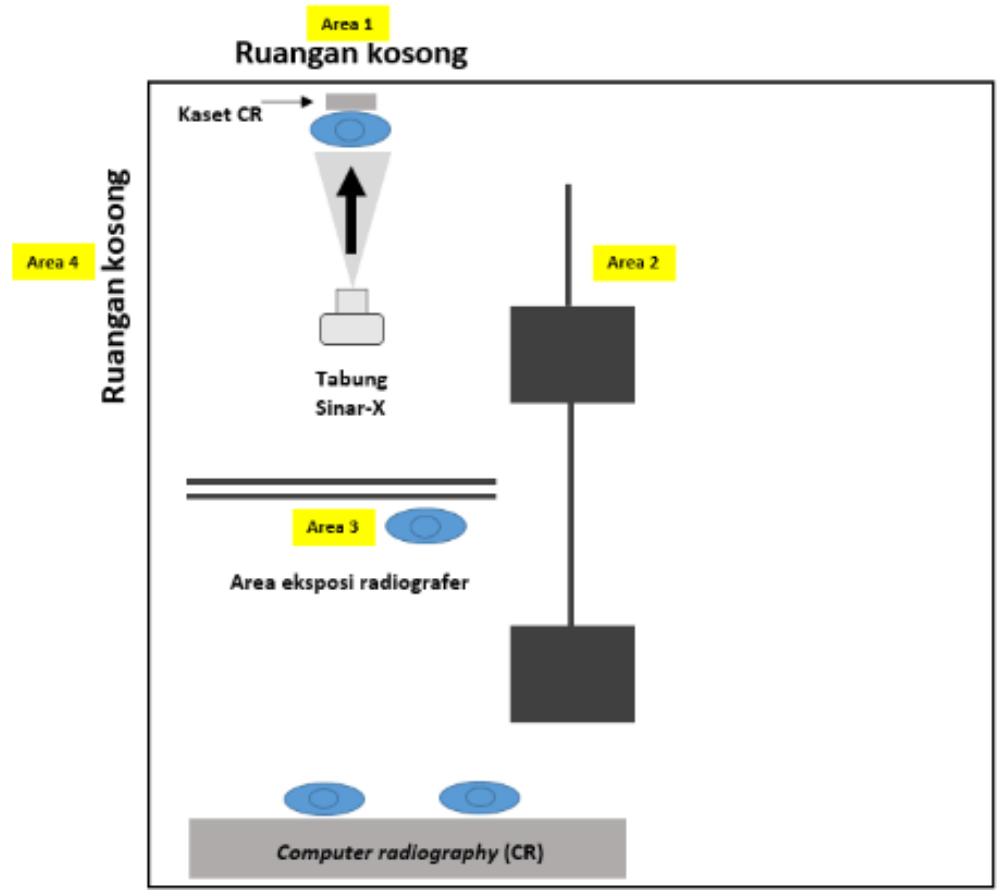

Gambar 2. Skema Instalasi radiologi

Penggunaan peralatan PACS dalam sistem pencitraan radiografi sangat membantu dalam komunikasi antara radiografer, dokter radiologi dan perawat/ dokter pengirimin. Sistem ini menyediakan pengiriman dan menyimpanan citra secara langsung sehingga perawat/ dokter pengirim dengan cepat mengetahui kondisi pasien setelah pemeriksaan radiografi. Hasil pengukuran paparan ruangan pemeriksaan radiografi, area $1=22,38 \mathrm{mR} / \mathrm{minggu}$, area $2=$ $5,23 \mathrm{mR} / \mathrm{minggu}$, area $3=7,32 \mathrm{mR} / \mathrm{minggu}$, area $4=8,67 \mathrm{mR} / \mathrm{minggu}$, sehingga paparan yang diterima masih dalam batas aman pada daerah pengendalian sedangkan pada daerah supervisi akan terus dipantau agar memastikan bahwa tidak ada aktivitas. Hasil ini juga 
menunjukan pada daerah aktvitas pekerja radiasi dosisi yang diterima belum melewati ambang batas $0,2 \mathrm{mSv} /$ minggu sesuai rekomendasi BAPETEN $(15,16)$.

\section{b. Kesiapan pekerja radiasi}

Setiap pekerja sebelum bekerja dilakukan pelatihan tentang pemahaman penyakit infeksius, kondisi pasien dan penggunaan APD, setelah itu setiap pekerja dilakukan pemeriksaan kesehatan dengan salah satunya screening menggunakan rapid test untuk memastikan bahwa setiap pekerja sehat dan terbebas dari COVID-19 sebelum melaksanakan tugas. Instalasi radiologi telah menetapkan Standar Operasional Prosedur (SOP) untuk para pekerja radiasi yang akan melakukan aktivitas di Instalasi radiologi, dimana selalu melakukan pengecekan peralatan APD yang akan digunakan, diantaranya pakaian pelindung/ gwon, head cover, surgical glove, masker N-95, kaos kaki, sepatu boot (Gambar 3). Apabila salah satu dari peralatan ini tidak tersedia maka pekerja tidak diperbolehkan masuk kedalam Instalasi Radiologi, setelah selesai kegiatan pelayanan radiologi para pekerja akan dilakukan dekontaminasi (Gambar 4). Pekerja radiasi yang berada diruangan pemeriksaan ; radiografer

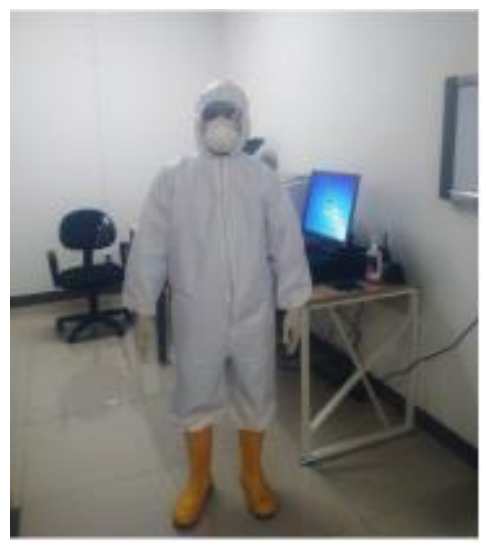

Gambar 3. Penggunaan APD

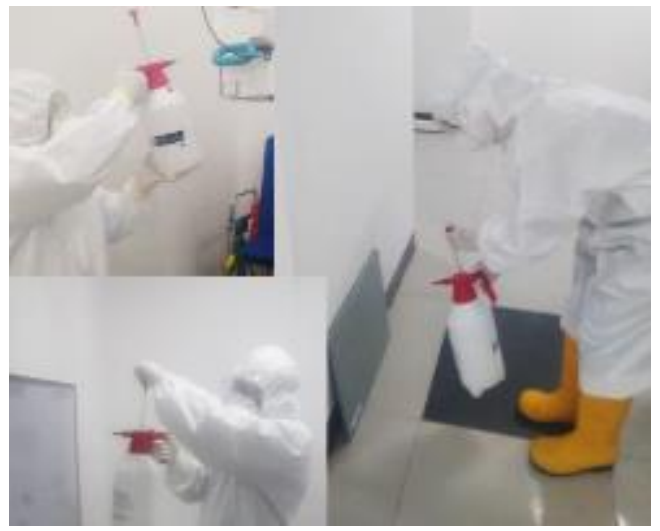

Gambar 5. Desinfektan peralatan

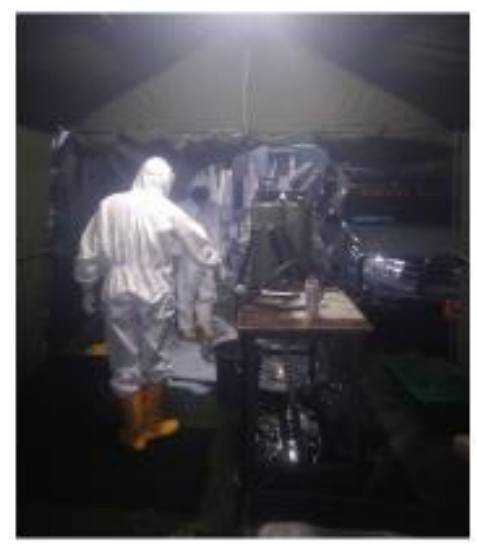

Gambar 4. Dekontaminasi APD

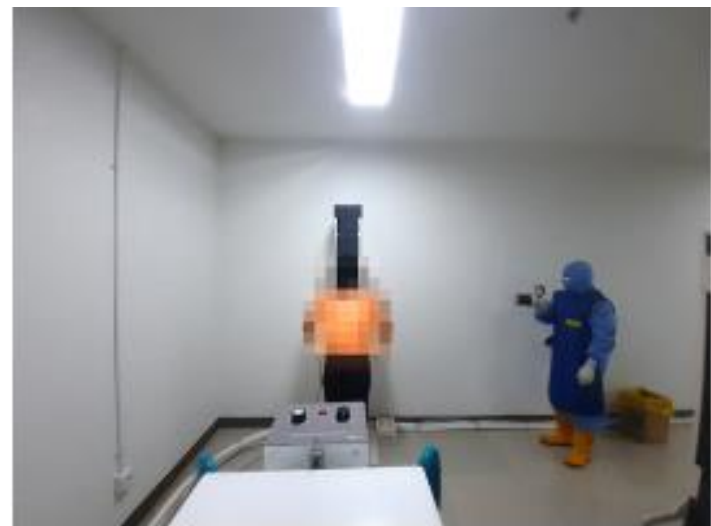

Gambar 6. Pengukuran paparan radiasi 
dan fisikawan medik. Tugas radiografer melaksakan pelayanan kepada pasien dengan melakukan pemeriksaan radiografi, kemudian melakukan optimalisasi citra hasil pemeriksaan radiografi sebelum dikirim ke dokter radiologi, setelah itu hasil citra di prin dan diberikan kepada perawat/ dokter pengirim, untuk memastikan keamanan bagi pasien dan pekerja, setiap selesai melakukan pemeriksaan radiografer akan selalu membersihkan peralatan dengan desinfektan (Gambar 5). Fisikawan medik melaksanakan pengukuran paparan radiasi di sekitar ruangan pemeriksaan radiografi, Quality control (QC) pesawat sinar-X mobile, QC CR, estimasi dosis radiasi pekerja dan pasien, serta melakukan repeat analysis citra radiografi, serta meninjau secara berkelanjutan program proteksi dan keselamatan radiasi (Gambar 6).

\section{c. Analisa pelayanan radiologi}

Pada masa pandemik COVID-19 pelayanan radiologi memiliki potensi peningkatan pasien yang sangat signifikan dari hari biasanya. Analisa pelayanan radiologi yang dilakukan tentang perhitungan beban kerja pekerja radiasi dan repeat analysis citra radiografi. Setelah mendapatkan nilai standar beban kerja kemudian dilakukan perhitungan kebutuhan SDM yang diperlukan dengan estimasi perkembangan jumlah pelayanan untuk bulan berikutnya 4000 untuk radiografer dan 8 untuk fisikawan medik. Perhitungan beban kerja tidak memasukan faktor kelonggaran kategorik karena hanya melakukan estimasi untuk masa pandemik. Dari hasil perhitungan analisa beban kerja degan metode WISN yang ditunjukan oleh Tabel 2, jumlah radiografer sedang bekerja yaitu 11 orang berdasarkan WISN bernilai $-4,3$ sehingga kebutuhan SDM radiografer untuk bulan berikutnya dalam masa pandemik menjadi 16 orang, sedangkan untuk fisikawan medik masih sesuai. Kegiatan pelayanan radiologi disesuaikan dengan kondisi, SDM dan peralatan tugas radiografer dan fisikawan medic $(17,18)$.

Tabel 2. Estimasi kebutuhan beban kerja dengan metode WISN

\begin{tabular}{lccccc}
\hline Kategori SDM & $\begin{array}{c}\text { Jumlah } \\
\text { SDM }\end{array}$ & $\begin{array}{c}\text { Beban } \\
\text { Kerja } \\
\text { Standar }\end{array}$ & $\begin{array}{c}\text { Jumlah } \\
\text { pelayanan bulan } \\
\text { berikutnya }\end{array}$ & $\begin{array}{c}\text { Kebutuhan } \\
\text { SDM }\end{array}$ & WISN \\
\hline Radiografer & 11 & 260 & 4000 & 15,3 & $-4,3$ \\
Fisikawan medik & 1 & 650 & 8 & 0,01 & 0,99 \\
\hline
\end{tabular}

Repeat analysis merupakan bagian dari departemen radiologi untuk menjaga Quality Assureance (QA) dengan melakukan analisa citra radiografi yang diterima 'accepted' atau tidak 'repeat' dengan disertai dengan alasan agar membantu mengidentifikasi masalah yang mungkin terjadi pada saat melakukan pemeriksaan radiografi, hal ini juga terkait dengan dosis radiasi yang diterima pasien. tujuan pemeriksaan radiologi untuk mendapatkan citra radiografi yang optimal dengan radiasi yang minimum kepada pasien, pada masa pandemik COVID-19. 
Repeat analysis juga digunakan sebagai indikator pengawasan minimal kontak pekerja dengan pasien pada saat melakukan pemeriksaan radiografi $(19,20)$.

Dari hasil reject analysis pada bulan maret-april 2020 16,6\% sedangkan pada bulan mei- juni 2020 1,77\% (Gambar 7). Berdasarkan hasil analisa ada beberapa alasan sehingga citra mengalami penolakan seperi artefak yaitu tampak objek yang seharusnya tidak ada atau objek yang mengganggu citra radiografi, terjadi cut off yaitu tidak mencakup kriteria radiografi (Gambar 8).

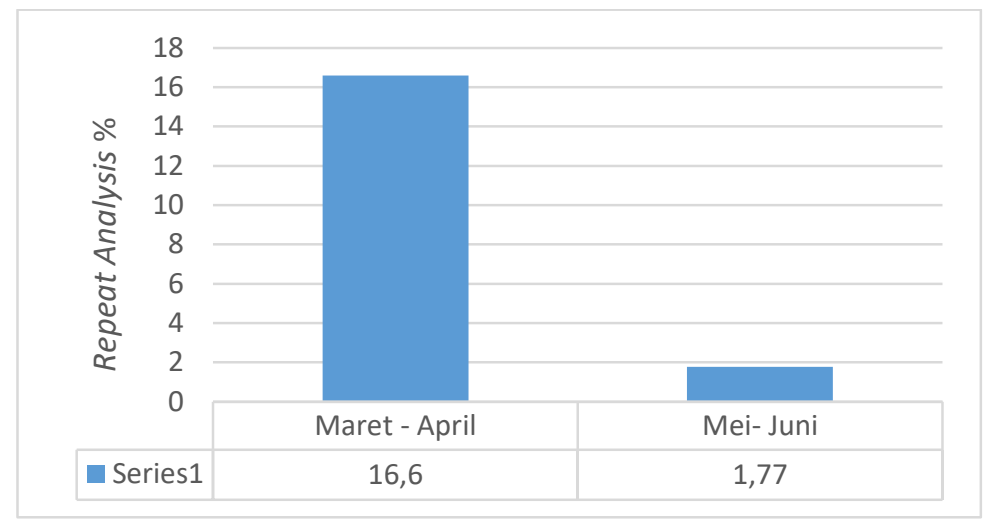

Gambar 7. Repeat Analysis

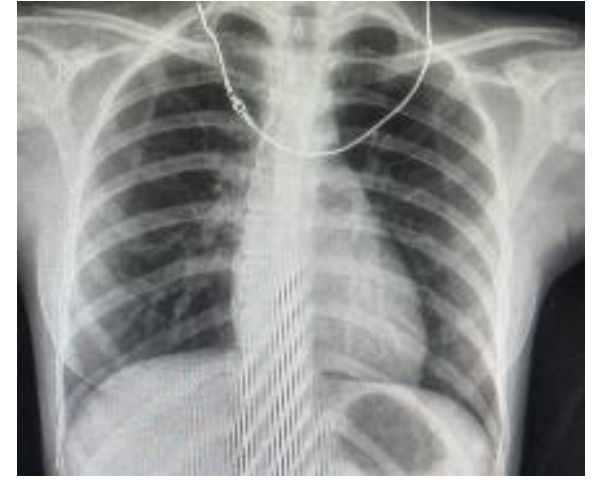

a) Citra artefak

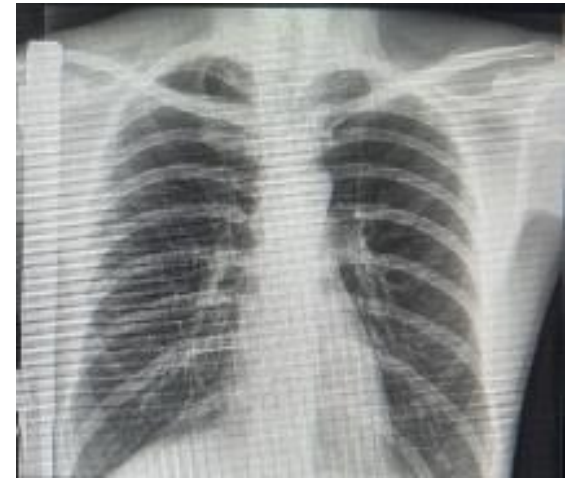

b) Citra cut off

Gambar 8 . Citra radiografi repeat

\section{d. Upaya proteksi dan keselamatan radiasi bagi pekerja dan pasien}

Pekerja radiasi mengedepankan prinsip proteksi radiasi yaitu Jarak, Waktu dan Shielding. 'Jarak' untuk pasien pemilihan FFD disesuaikan se-optimal mungkin dengan pertimbangan prosedur pemeriksaan radiografi dan faktor ekposi yang digunakan. Sedangkan untuk pekerja radiasi mempertimbangkan jarak yang aman dari tabung ke posisi pekerja radiasi, karena jumlah paparan radiasi berbanding terbalik dengan kuadrat jarak, oleh karena itu dengan menguapayakan jarak menjadi $2 x$ dari jarak mula-mula maka dapat mengurangi paparan radiasi tidak menjadi $1 / 2$ tetapi menjadi $1 / 4(21,22)$. 
'Waktu' hal ini berhubungan dengan penggunaan parameter faktor eksposi kepada pasien. parameter harus di upayakan se-optimal mungkin, sebelum melakukan pemilihan parameter faktor eksposi kepada pasien, pekerja radiasi sebaiknya mempertimbangkan jarak FFD yang digunakan, ketebalan pasien, dan menggunakan faktor ekposi yang direkomendasikan oleh pesawat sinar-X tersebut. Selain itu waktu juga berhubungan dengan beban kerja, karena bagi pekerja radiasi didalam instalasi radiologi pada masa pandemik seperti ini bukan hanya COVID-19 tetapi potensi bahaya radiasi juga perlu diperhatikan sehingga peran pengaturan shift pekerja radiasi juga menjadi pertimbangan agar mengurangi paparan kepada pekerja radiasi. Selain itu dalam praketknya berdasarkan KMK tentang pelayanan radiologi bahwa beban kerja ideal yaitu 1 pesawat sinar-X dengan 2 radiografer (18), akan tetapi karena pelayanan yang dilakukan kepada pasien COVID-19, sehingga agar meminimalkan kondisi terinfeksi COVID-19, paparan radiasi pada saat pemeriksaan dan kelelahan akibat menggunakan APD, maka sesuai dengan kondisi pelayanan di lapangan dibutuhkan 3 radiografer untuk mengopersikan 1 pesawat sinar-X.

'Shielding' perlunya kesadaran para pekerja radiasi, instalasi radiologi menyediakan mobile shielding dan apron untuk mengurangi potensi menerima paparan radiasi. Mobile shielding berjumlah 6 buah dan 2 apron, sehingga para pekerja dapat mengupayakan proteksi dan keselamat radiasi pada saat pemeriksaan radiografi dilakukan (15).

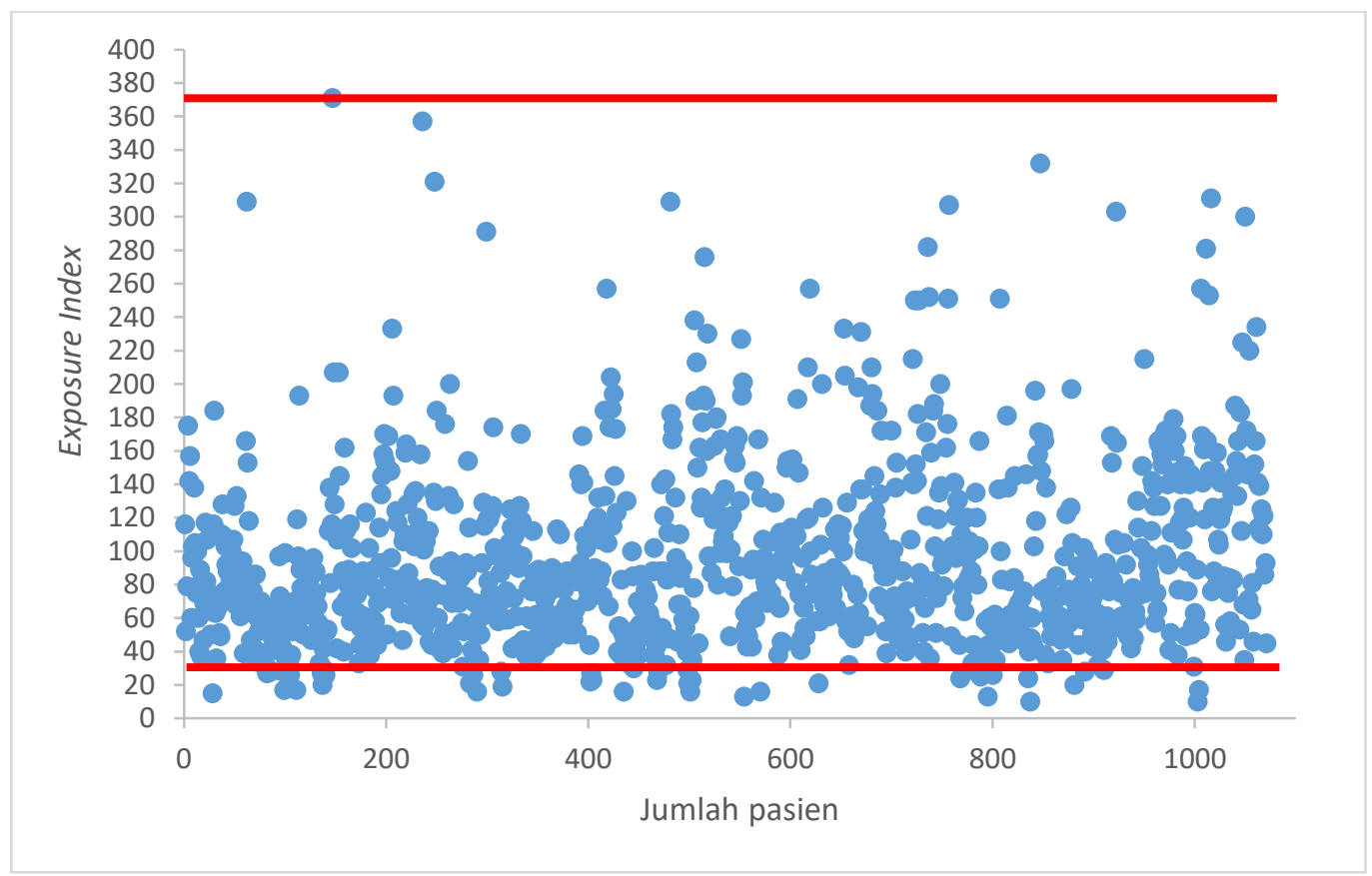

Gambar 9. Exposure Index Bulan Juni 2020 
Secara klinis upaya optimasi yang dilakukan kepada pasien pemeriksaan radiografi dana dapat dilakukan dengan evaluasi exposure index (EI) $(23,24)$, hal ini dilakukan sehingga radiografer dapat mengontrol paparan radiasi yang diberikan kepada pasien sesuai dengan informasi yang diberikan oleh EI. Pada Gambar 9 menunjukan bahwa radiografer telah mengupayakan pengendalian dosis radiasi secara optimal dengan hasil indikator rentang EI 30370 (20). Selain itu radiografer memaksimalkan post processing untuk meningkat kualitas citra dalam penggunaan computer radiography maka citra mampu dioptimisasikan dan dapat menurunkan kejadian pengulangan pemeriksaan dada. Dalam kondisi pandemi COVID-19, semua pasien pemeriksaan dada merupakan suspected COVID-19 sehingga dengan tidak melakukan pengulangan pemeriksaan maka menurunkan resiko kontak dan resiko terinfeksi COVID-19 $(19,20)$.

\section{KESIMPULAN}

Kesimpulan untuk kondisi ruangan dan peralatan sangat memadai dalam melaksanakan pemeriksaan radiografi, kondisi pekerja dilengkapi dengan APD sesuai SOP penanganan COVID-19, pelayanan radiologi berdasarkan analisa WISN dibutuhkan 16 radiografer dengan estimasi jumlah pemeriksaan radiografi dada 4000 pasien, dan 1 fisikawan medik. Dalam penerapan proteksi radiasi agar memperhatikan prinsip jarak, waktu dan shielding.

\section{UCAPAN TERIMA KASIH}

Peniliti mengucapkan terima kasih kepada semua radiografer RS Darurat COVID-19 Wisma Atlet Jakarta dan pihak yang telah berkontribusi terhadap penelitian ini. Penulis menyatakan tidak ada konflik kepentingan dengan pihak-pihak yang terkait dalam penelitian ini.

\section{DAFTAR PUSTAKA}

1. Dr Daniel J Bell. COVID-19 | Radiology Reference Article | Radiopaedia.org. https://radiopaedia.org/articles/covid-19-3?lang=us). Published 2020. Accessed June 13, 2020.

2. Alvin MD, George E, Deng F, Warhadpande S, Lee SI. The Impact of COVID-19 on Radiology Trainees. Radiology. March 2020. doi:10.1148/radiol.2020201222

3. Mossa-Basha M, Medverd J, Linnau K, et al. Policies and Guidelines for COVID-19 Preparedness: Experiences from the University of Washington. Radiology. April 2020:201326. doi:10.1148/radiol.2020201326

4. Pan F, Ye T, Sun P, et al. Time Course of Lung Changes On Chest CT During Recovery From 2019 Novel Coronavirus (COVID-19) Pneumonia. Radiology. June 2020:200370. doi:10.1148/radiol.2020200370

5. Rubin GD, Haramati LB, Kanne JP, et al. The Role of Chest Imaging in Patient Management during the COVID-19 Pandemic: A Multinational Consensus Statement 
from the Fleischner Society. Radiology. April 2020:201365. doi:10.1148/radiol.2020201365

6. Ai T, Yang Z, Hou H, et al. Correlation of Chest CT and RT-PCR Testing in Coronavirus Disease 2019 (COVID-19) in China: A Report of 1014 Cases. Radiology. February 2020:200642. doi:10.1148/radiol.2020200642

7. Mossa-Basha M, Meltzer CC, Kim DC, Tuite MJ, Kolli KP, Tan BS. Radiology Department Preparedness for COVID-19: Radiology Scientific Expert Panel. Radiology. March 2020:200988. doi:10.1148/radiol.2020200988

8. Zhao W, Zhong Z, Xie X, Yu Q, Liu J. Relation Between Chest CT Findings and Clinical Conditions of Coronavirus Disease (COVID-19) Pneumonia: A Multicenter Study. Am J Roentgenol. 2020;214(5):1072-1077. doi:10.2214/AJR.20.22976

9. Franquet T. Imaging of pulmonary viral pneumonia. Radiology. 2011;260(1):18-39. doi:10.1148/radiol.11092149

10. Mazzone PJ, Gould MK, Arenberg DA, et al. Management of Lung Nodules and Lung Cancer Screening During the COVID-19 Pandemic: CHEST Expert Panel Report. Radiol Imaging Cancer. 2020;2(3):e204013. doi:10.1148/rycan.2020204013

11. KMK. Menteri Kesehatan Republik Indonesia Nomor: 129/Menkes/SK/II/2008. 2008:55.

12. Brian C. Hospital gets creative to perform safer COVID-19 X-rays. https://www.auntminnie.com/index.aspx?sec=sup\&sub=wom\&pag=dis\&ItemID=1287 82. Published 2020. Accessed June 13, 2020.

13. Tsou IYY, Liew CJY, Tan BP, et al. Planning and coordination of the radiological response to the coronavirus disease 2019 (COVID-19) pandemic: the Singapore experience. Clin Radiol. 2020;75(6):415. doi:10.1016/j.crad.2020.03.028

14. Ng M-Y, Lee EY, Yang J, et al. Imaging Profile of the COVID-19 Infection: Radiologic Findings and Literature Review. Radiol Cardiothorac Imaging. 2020;2(1):e200034. doi:10.1148/ryct.2020200034

15. Irsal M, Syuhada FA, Ananda YP, Putra AGP, Syahputera MR, Wibowo S. Measurement of Radiation Exposure in Facilities for Radiology Diagnostic At the Covid-19 Emergency Hospital in Wisma Atlet Jakarta. J Vocat Heal Stud. 2020;4(2):55. doi:10.20473/jvhs.v4.i2.2020.55-61

16. BAPETEN. Perka BAPETEN Nomor 8 Tahun 2011 tentang Keselamatan Radiasi dalam Penggunaan Pesawat Sinar-X Radiologi Diagnostik dan Intervensional. 2011:1-55.

17. KMK. Keputusan Menteri Kesehatan Republik Indonesia Nomor : 81/ MENKES/ SK/ I/ 2004. 2004:1-53. http://dinkes.inhukab.go.id/wpcontent/uploads/2015/04/Kepmenkes-No-81-Th-2004-ttg-pedoman-penyusunanperencanaan-SDM-Kesehatan.pdf.

18. KMK. Keputusan Menteri Kesehatan Republik Indonesia Nomor : 1014/MENKES/SK/XI/2008. 2008:34.

19. Irsal M. Evaluasi Faktor Eksposi dalam Upaya Optimisasi pada Pemeriksaan Radiografi Chest PA Suspected COVID - 19. KOCENIN Ser Konf. 2020;(October):1-10. http://publikasi.kocenin.com/index.php/pakar/article/view/26/21.

20. Irsal M, Syuhada FA, Ananda YP, et al. Analysis Exposure Index As an Optimization Effort on Examination Chest Posterior Anterior. J Vocat Heal Stud. 2020;4(2):50. doi:10.20473/jvhs.v4.i2.2020.50-54

21. Kim JH. Three principles for radiation safety: Time, distance, and shielding. Korean $J$ Pain. 2018;31(3):145-146. doi:10.3344/kjp.2018.31.3.145

22. Lubis LE, Nastiti Y, Anam C, et al. Rekomendasi AFISMI No.1 : Penggunaan Radiasi Pengion dalam Diagnosis dan Penanganan COVID-19. 2020:1-18.

23. Irsal M. Exposure Factor Control with Exposure Index Guide As Optimizing Efforts in 
Chest PA Examination. J Phys Conf Ser. 2021;1842(1):0-6. doi:10.1088/17426596/1842/1/012059

24. Irsal M, Suroso B, Ichsan M, Yansyah A. Peningkatan Pemahaman Radiografer Terhadap Diagnostic Reference Level Sebagai Upaya Optimisasi Pemeriksaan. J Heal. 2021;8(1):1-10. 